\title{
Através do Universo: Notas sobre as constelações na cosmologia Tukano ${ }^{1}$
}

Melissa Santana de Oliveira ${ }^{\mathrm{a}}$

Este artigo tem como objetivo apresentar algumas notas antropológicas sobre concepções astronômicas dos Tukano, demonstrando sua articulação com noções relativas à organização social e cosmologia. Mais especificamente tratará sobre a classificação Tukano das constelações e sua categorização como Gente-estrela (Ñohkoa Mahsã), o registro de nomes e listas de constelações Tukano na literatura, as relações estabelecidas pelos Tukano entre o ciclo de constelações e demais ciclos anuais e sobre a imagem das constelações na mitologia Tukano ressaltando seu profundo significado ritual.

Astronomia; Cosmologia; Tukano Orientais; Noroeste Amazônico.

Os grupos Tukano² são exímios observadores do céu e dos fenômenos que a ciência ocidental denomina astronômicos. Não raro procuram mostrar aos que entre eles se encontram as constelações, a lua, o sol, Vênus, o arco íris, as estrelas cadentes e a Via Láctea, apontando-os, nomeando-os e contando suas histórias. As constelações têm sido há muito tempo foco do interesse e da descrição de estudiosos da região do alto Rio Negro - viajantes, missionários, antropólogos e mais recentemente das publicações realizadas pelos próprios conhecedores indígenas ${ }^{3}$.

a Pesquisadora de Pós-Doutorado (FAPESP) no Programa de Pós Graduação em Antropologia Social (UFSCar). Email: melzita.oliveira@gmail.com. 
Nohkoã Mahsã (gente estrela): classificação Tukano das constelações.

Os Tukano possuem um modo próprio de conceber e classificar as constelações, que são denominadas Nohkoa mahsã (Gente estrela), seres que vivem na Umuse pati (Camada do céu) e que se originaram na época dos Bahuari mahsã (Gente do aparecimento), primeira humanidade que habitava, na $U$ mttse Wikhã (Maloca do Céu) e que realizou imersões neste mundo para propiciar as condições de existência da humanidade atual ${ }^{4}$. Certos episódios da mitologia descrevem como seres ou objetos lançados no céu se transformaram em Nohkoa mahsã (gente humana). De acordo com o kumu (especialista xamânico) Kumarõ Guilherme Azevedo, Tukano, clẵ Hausirõ porã, o brilho dos Nohkoa mahsã advém dos objetos de ouro que estes seres possuem, como brincos e bancos. Para o kumu José Azevedo, Tukano, clã Ñahuri porã, as constelações são também seres perigosos e venenosos, por isso não encostam uns nos outros e guardam certa distância entre si no espaço.

Categorizadas como mahsã (gentes), as constelações estão inseridas em um sistema de compreensão, classificação e ordenação do mundo no qual noções de parentesco e de socialidade que têm como idioma central a hierarquia e a segmentação, que diferencia clãs e gerações por ordem de senioridade, algo que se estende a outros domínios, de modo a reger as relações entre as diversas 'gentes' que habitam o $\operatorname{cosmos}^{6}$. Dentre as constelações que compõem um ciclo astronômico anual, os Tukano e Desana do médio Tiquié, distinguem algumas que consideram 'constelações-chefes', as 'mais importantes': Aña (Jararaca), Pamo (Tatu), Muthã (Jacundá), Dahsitt (Camarão), Yai (Onça), Nohkoa Tero (Conjunto de estrelas), Wai kahsa (Jirau de peixe), Sio Yahpu (Cabo de Enxó), Diayo (Lontra), Yhe (Garça). Estas constelações são chamadas de Nonkoa diarã mahsã (Gente estrela real). Diarã, termo comumente traduzido como 'reais' e 'puras', também é utilizado na definição de pessoas e grupos, por exemplo, acrescenta-se diagtt (real, puro, masc. sing) ao etnônimo Yepa mahsu (Gente terra, masc. sing.), em referência a um Tukano legítimo (ver Ramirez: 1997:39). As constelações-chefes são aquelas maiores em extensão e cujo ocaso em 
certa época do ano é relacionado 'às grandes chuvas', conformando períodos longos de inverno. Bihpia (Pássaro), Purĩ (Folhas), Yaka (Peixe Cascudo), Namia (Formigas da noite), são consideradas medianamente importantes, pois são pequenas e estão relacionadas à um período curto de chuvas, e muitos conhecedores nem sabem em que área do céu elas estão localizadas. Siphe pairo (Espécie de Jararaca), Uphaigu (Jabuti), Namakuro pe (Túmlo de Ñamakuru), Kai sarirõ (Gaiola de periquito) não estão relacionadas a ocorrência de chuvas.

Diakuru \& Kisibi (2006), ambos Desana, clã Wahari diputiro porã, também diferenciam entre as constelações que definem épocas e as que não definem:

"Há várias outras constelações no céu que [...] não indicam nenhuma estação do ano. Elas sempre ficam no mesmo lugar no céu, tais como gã̃̃ sarirõ (gaiola dos periquitos), Muñu (piranha) ou ainda Namakuru Masá gobé (túmulo de Namakuru)" e Uta boho sere (cruz de pedra de quartzo)" (Diakuru \& Kisibi 2006:39).

Miguel Azevedo, Tukano, clã Hausiro Porã, insere as constelações Aña e Siphe Pairo na família das Aña mahsã (Gente- Jararaca) que classifica:

"Entre a Gente-Jararaca a primeira é Aña diaso (jararaca ribeirinha), depois vem Aña siphe phairo (jararaca de ânus grande), depois Sokosero (cascavel) e Kometero (coral). Aña diaso é considerada mami (irmão maior), de todas as jararacas; Aña siphe phairo é considerada $k_{u}$ ahkabi (seu irmão menor). Estas duas jararacas podem ser vistas como constelações no céu" (Comunicação pessoal, tradução Seribhi Dário Azevedo).

Certas constelações que realizam o ocaso concomitantemente ou seguidamente são consideradas Nohkoã bahparã (constelações companheiras), por exemplo, a dupla Mttha e Dahsitt, o conjunto Nohkoa tero, Wai Kahsa, Sio Yahpu; e o grupo Diayo e Yaka, Bihpia, Namia, Purĩ, Tohto, das quais, segundo Roberval Pedrosa, Tukano, clã Nahuri porã (comunicação pessoal), a primeira é considerada 'chefe'. Essa definição guarda certa equivalência com a classificação Barasana do céu 
registrada por Hugh-Jones (1981). Segundo o autor, as principais constelações Barasana estão ao longo da Via Láctea ou Caminho das Estrelas-Ñohkoa Ma e embora toda a trajetória das estrelas seja de leste a oeste, a orientação diagonal da Via Láctea em relação à eclíptica ${ }^{7}$ serve para dividir o caminho das estrelas em dois segmentos: Novo Caminho (mama ma), sudeste-noroeste e Velho Caminho (buku ma), nordeste-sudoeste. Em cada um destes caminhos há um grupo de constelações e uma delas é considerada focal (Nyokoaro, Pleiades, no Novo caminho e o Jaguar Lagarto, Scorpious, no Velho Caminho) e as outras suas Ĩya Yai 'companheiras' (Hugh-Jones 1981). Conforme demonstrei em Oliveira (2016:61) Bahpa-, cuja tradução é par ou companheiro, é uma noção central que perpassa vários aspectos das relações sociais Tukano, designando a composição de duplas dialógicas em contexto de trabalho, guerra e rituais.

Aña (Jararaca), Pamo (Tatu) e Yai (Onça), são constelações consideradas segmentadas, divididas de acordo com partes dos corpos dos animais que as nomeiam. A constelação Aña (Jararaca) é composta por: Aña siõkhã (estrela que ilumina a jararaca), Aña duthooa (cabeça), Aña nimaga (bolsa de veneno), Aña ñemeturi (fígado), Aña dieripa (ovos), Aña uhpu (corpo) e Aña pihkorõ (rabo). Pamo (Tatu) é composta por: Pamo siõkhã (estrela que ilumina o tatu), Pamo oaduhka (osso), Pamo ohpu (corpo) e pamo pihkorõ (rabo). Yai (Onça) está dividida em: Yai siõkhã (estrela que ilumina a onça), Yai useka poari (bigode), Yai duhpoa (cabeça), Yai ohpu (corpo) e Yai pihkorõ (rabo). A segmentação das constelações também pode ser compreendida à luz do sistema de organização social Tukano. A sua divisão entre cabeça, corpo e rabo guarda relação inegável com os termos utilizados na classificação dos clãs Tukano. Cada clã é considerado derivado de uma parte específica do corpo da anaconda ancestral - cabeça, corpo ou rabo - o que estabelece uma ordem hierárquica entre os mesmos: os clãs de mais alto nível são considerados derivados da 'cabeça' e os de mais baixo são considerados 'rabo'.

Como veremos mais adiante, as narrativas de origem destas constelações segmentadas descrevem episódios em que personagens foram 
mortos, cortados, despedaçados, e lançados ao céu, transformandose em Ñohkoa mahsã (Gente estrela), em constelações. Neste sentido, Hugh- Jones demonstrou como morte, segmentação e transformação, são elementos que estão correlacionados na mitologia e na organização social Tukano:

\begin{abstract}
"No mito, a morte e a destruição de uma fonte única leva a segmentação e a continuidade de suas partes: o corpo da anaconda ancestral origina filhos que vivem através de seus descendentes, ou origina o Yurupari que vive no mundo He. Na comunidade da maloca, homens dão origem a filhos que por sua vez originam seus descendentes. Quando a geração sênior morre, seus filhos separam-se e formam novas comunidades..." (Hugh-Jones 1979:249-250 - Tradução nossa).
\end{abstract}

Dentre as partes que compõem as constelações está o siōkha, que já foi registrado na literatura por Koch-Grünberg (2009 [1905]) como 'facho', Ribeiro e Kenhiri (1987) como 'iluminação', Ñahuri \& Kumaro (2003), Cardoso (2007) e Correa (1997), como 'turi', tipo de luminária abastecida com breu utilizada para iluminação noturna.

Por siõkhã conhecedores Tukano e Desana do médio rio Tiquié se referem à uma estrela que fica próxima ou à frente de uma determinada constelação, e cujo ocaso é associado às primeiras chuvas que esta constelação demarca. Está lá para iluminar, guiar o caminho das constelações no seu movimento de passagem pelo céu (leste-oeste). Este sentido se aproxima daquele encontrado por Correa (1997:154) entre os Cubeo, para o camaru (turi), estrela que se põe antes de uma constelação anunciando sua declinação próxima e que é considerada guia da constelação que leva seu nome. Em Ramirez (1997:169) 'sĩ'áo' é traduzido por propagar a luz, alumiar, focar compondo com 'kaha' sufixo verbal que indica a forma redonda ou cilíndrica, sĩ’akahá, lanterna, isqueiro e sĩáokaha, lâmpada, lamparina. No depoimento de José Azevedo, Tukano, clã Nahuri porã, traduzido por seu filho, Dario Alves Aze- 
vedo, o siõkhã, e mesmo as constelações, alcançam um significado mais profundo, relacionado ao contexto ritual:

"Os siõkhã são as estrelas que estão na frente das constelações e recebem o nome dos irmãos chefes [irmãos ancestrais dos Tukano]. A primeira estrela de Aña [Jararaca] é Yupuri, que está iluminando essa jararaca, Seribhi, irmão menor de Yupuri, vem na frente de Pamo [Tatu], Doe está na frente de Yai duthooa [Cabeça da Onça]... Todos os ornamentos que a pessoa usa, seja o kumu ou o pajé (especialistas xamânicos) - os ornamentos de cabeça, o colar de quartzo, o cinto de dentes de onça, yuhtasero [faixa de baixo do joelho], kihtio [chocalho que se põe nos tornozelos], até as flautas sagradas - todos os ornamentos deles, isso que eles estão alumiando para poder proteger mesmo... Eles guardam os ornamentos onde eles moram... Por isso que tem umas estrelas assim perto das constelações... Estas estrelas iluminam estas constelações e dentro destas constelações estão todos estes ornamentos..."

\section{Nomes e listas de constelações na literatura sobre os Tukano.}

De acordo com Hugh-Jones (1981:189) entre os Barasana os nomes das constelações pertencem a um pequeno número de classes: pássaros, frutas, insetos, peixes, outras criaturas aquáticas e alguns objetos de manufatura, e não há estrelas nomeadas com animais de caça, seres mais relacionados a terra e a uma atividade econômica que é menos afetada por mudanças sazonais. Essa afirmação pode ser estendida aos demais Tukano, porém devemos atentar para a existência de uma constelação que leva o nome de um animal de caça - Pamo (Tatu), inclusive entre os Barasana.

É possível identificar na literatura sobre os Tukano, um ciclo de constelações reconhecido por quase todos os grupos assim denominadas: Jararaca (ou arraia), Tatu, Jacundá, Camarão, Onça, Conjunto de estrelas (ou coisa estrela), Jirau de peixe, Cabo de enxó, Ararinha, Garça (Epps \& Oliveira 2013:97). Na tabela abaixo apresento nomes de constelações que são recorrentes no registro de diversos autores sobre diferentes grupos Tukano: 
ANTHROPOLÓGICAS 28(1):134-168, 2017

\begin{tabular}{|c|c|c|c|c|}
\hline \multirow[b]{2}{*}{ Nome em português } & \multicolumn{4}{|c|}{ Nome na língua indigena } \\
\hline & $\begin{array}{l}\text { Tukano Desana. } \\
\text { Aeity \& Acimet } \\
\text { (2008); Cardoso } \\
\text { (2007). *registro } \\
\text { em Tukano. }\end{array}$ & $\begin{array}{l}\text { Tukano. } \\
\text { Silva (1962). }\end{array}$ & $\begin{array}{l}\text { Desana. } \\
\text { Ribeiro \& Ke- } \\
\text { nhiri (1995); } \\
\text { Diakuru \& } \\
\text { Kisibi (2006). }\end{array}$ & (AietU 2009). \\
\hline $\begin{array}{l}\text { Jararaca } \\
\text { Arraia (Tukano) }\end{array}$ & Aña & Aña & Aña & Aña \\
\hline Tatu & Pamo & & Pamo & Pamo \\
\hline Jacundá & Mtthã & & & Muña \\
\hline Camarão & Dahsitt & $\begin{array}{l}\text { Daxsyã } \\
\text { pikõ-rõ }\end{array}$ & $\begin{array}{l}\text { Nahsin kamë } \\
\text { Nasi kamut }\end{array}$ & 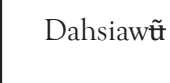 \\
\hline Onça & Yai & Yaí & $\begin{array}{l}\text { Yé } \\
\text { Ye }\end{array}$ & Yai \\
\hline Conjunto de estrelas & Nohkoa Tero & Yõxkwãtéro & Neka turu & Nokoatero \\
\hline Jirau de peixe (moquém) & Wai Kahsa & Wai Kaxsá & $\begin{array}{l}\text { Wai kaiá } \\
\text { Wai kaya }\end{array}$ & Wai kasa \\
\hline $\begin{array}{l}\text { Suporte de cérebro } \\
\text { (Tukano e Desana) } \\
\text { Armadilha para periqui- } \\
\text { to (Desana) } \\
\text { Suporte de polpa } \\
\text { de umari (Tukano e } \\
\text { Desana) }\end{array}$ & Kai Sarirõ & & $\begin{array}{l}\text { Kai Saninó } \\
\text { Gaĩ Sarirõ }\end{array}$ & \\
\hline Cabo de enxó & Sio Yahpu & Sió-Yaxpú & $\begin{array}{c}\text { Yohoká } \\
\text { dëhpë } \\
\text { Yohoka } \\
\text { dupt }\end{array}$ & Sio Yapu \\
\hline Lontra & Diayo & Diá-yó & Di'ayowá & \\
\hline Garça & Yhe & & $\begin{array}{l}\text { Iahí } \\
\text { Yahí }\end{array}$ & $\mathrm{Ye}$ \\
\hline
\end{tabular}

Tabela 1. Constelações Tukano registradas por diferentes autores. 
Oliveira: Através do Universo

\begin{tabular}{|c|c|c|c|c|}
\hline \multirow[b]{2}{*}{ Nome em português } & \multicolumn{4}{|c|}{ Nome na língua indigena } \\
\hline & $\begin{array}{l}\text { Pira Tapuia. } \\
\text { Silva (1962). }\end{array}$ & $\begin{array}{l}\text { Miriti-Tapuia. } \\
\text { Koch-Grünberg } \\
\text { (2009 [1905]. } \\
\text { * registro em } \\
\text { português }\end{array}$ & $\begin{array}{l}\text { Barasana. } \\
\text { Hugh Jones } \\
(1981)\end{array}$ & $\begin{array}{l}\text { Kubeo. } \\
\text { Correa (1987). } \\
\text { Koch-Grünberg } \\
(2009 \text { [1905]. }\end{array}$ \\
\hline $\begin{array}{l}\text { Jararaca } \\
\text { Arraia (Pira Tapuia) }\end{array}$ & Aña & Cobra grande & Anya & Ainku \\
\hline Tatu & Pamõ & Tatu & Hamo & Pamuru \\
\hline Jacundá & Mahõã & & Muha buhua & \\
\hline Camarão & Daxsyã & & Rasikamt & $\begin{array}{l}\text { Najoco kijiko } \\
\text { Najoco uraco }\end{array}$ \\
\hline Onça Lagarta (Barasana) & Yai & Onça & -ya Yai & Yawi \\
\hline $\begin{array}{l}\text { Conjunto de estrelas } \\
\text { Enxame de vespas (Ku- } \\
\text { beo e Barasana) }\end{array}$ & Yõxkwãtéro & $\begin{array}{l}\text { Sem denomi- } \\
\text { nação }\end{array}$ & $\begin{array}{l}\text { Nyokoaro } \\
\text { Nyokoaro } \\
\text { buktrã }\end{array}$ & $\begin{array}{l}\text { Uchiwu } \\
\text { Uchiwu ma- } \\
\text { jiowaro }\end{array}$ \\
\hline Jirau de peixe (moquém) & Wai kaxsá & $\begin{array}{l}\text { Jirau para assar } \\
\text { peixe }\end{array}$ & Wai kasabo & Moa cadawa \\
\hline $\begin{array}{l}\text { Armadilha para periqui- } \\
\text { to (Pira Tapuia) } \\
\text { Suporte de polpa de } \\
\text { umari (Barasana) }\end{array}$ & Kaĩ Sã'rũrõ & & $\begin{array}{l}\text { Wamt saniro } \\
\text { kihika } \\
\text { Wamt saniro } \\
\text { phaigtt }\end{array}$ & Emindo (?) \\
\hline Cabo de enxó & Syó- Yaxpú & & $\begin{array}{l}\text { Siorththt } \\
\text { Sioruht } \\
\text { buthktrã }\end{array}$ & $\begin{array}{l}\text { Tuipe ma- } \\
\text { jiowaro } \\
\text { Tuipe }\end{array}$ \\
\hline $\begin{array}{l}\text { Lontra } \\
\text { Ariranha }(\mathrm{Kb})\end{array}$ & Dia-yó & & $\begin{array}{l}\text { Timi haigtt } \\
\text { Maha hesatt } \\
\text { Wania timia } \\
\text { Hia timia }\end{array}$ & Jiádawiwa \\
\hline Garça & Yehé & Garça & & Yaiwa \\
\hline
\end{tabular}

Tabela 1. Constelações Tukano registradas por diferentes autores (Cont.). 
Apesar da equivalência entre nomes de constelações de diferentes povos, apenas em alguns casos os registros coincidem no que diz respeito à correspondência entre nome da constelação e área de referência no céu não-indígena em que ela está localizada. É o caso da constelação Aña (Jararaca), recorrentemente relacionada à região de Scorpius, Nohkoa Tero (Conjunto de estrelas ou coisa estrela), relacionada a Plêiades, Wai Kahsa (Jirau de peixe) à Hyades e Sio Yahpu (Cabo de enxó) à Orion (Epps \& Oliveira 2013:100).

\begin{tabular}{|c|c|c|c|c|c|}
\hline \multirow[b]{2}{*}{$\begin{array}{l}\text { Constela- } \\
\text { ção }\end{array}$} & \multicolumn{5}{|c|}{ Área de referência no céu não-índio } \\
\hline & $\begin{array}{l}\text { Tukano e Desana } \\
\text { Cardoso (2007). }\end{array}$ & $\begin{array}{l}\text { Desana. } \\
\text { Ribeiro \& Ke- } \\
\text { nhiri (1995). }\end{array}$ & $\begin{array}{l}\text { Miriti Tapuia. } \\
\text { Koch- } \\
\text { Grünberg } \\
\text { (2009 [1905]). }\end{array}$ & $\begin{array}{l}\text { Barasana. } \\
\text { Hugh- } \\
\text { Jones, } \\
\text { (1981). }\end{array}$ & $\begin{array}{l}\text { Kubeo. } \\
\text { Correa (1987) } \\
\text { Koch- } \\
\text { Grünberg } \\
\text { (2009 [1905]). }\end{array}$ \\
\hline Jararaca & $\begin{array}{l}\text { Libra, Corvo, Escor- } \\
\text { pião, Escorpião, } \\
\text { Sagitário }\end{array}$ & $\begin{array}{l}\text { Cruzeiro do } \\
\text { Sul, Cinturão } \\
\text { de Orion, } \\
\text { Alfa e Beta do } \\
\text { Centauro, } \\
\text { Cauda do } \\
\text { Escorpião }\end{array}$ & Scorpius & $\begin{array}{l}\text { Corona } \\
\text { Australis }\end{array}$ & $\begin{array}{l}\text { Scorpius, } \\
\text { Antares } \\
\text { Libra, Scor- } \\
\text { pius }\end{array}$ \\
\hline Tatu & $\begin{array}{l}\text { Águia e Vulpécula, } \\
\text { Seta }\end{array}$ & & Coroa & $\begin{array}{l}\text { Corona } \\
\text { Borealis }\end{array}$ & Coroa \\
\hline Jacundá & Estrelas de Aquário & & & $\begin{array}{l}\text { Rigel ( } \beta \text { de } \\
\text { Orion) }\end{array}$ & \\
\hline Camarão & $\begin{array}{l}\text { Catálogo de Hippar- } \\
\text { cus e Estrelas de } \\
\text { Aquário }\end{array}$ & & & $\begin{array}{l}\text { provavel- } \\
\text { mente } \\
\text { forma parte } \\
\text { do Leo }\end{array}$ & $\begin{array}{l}\text { Indi, Grulla } \\
\text { Piscis Aus- } \\
\text { trinus, } \\
\text { Aquarius }\end{array}$ \\
\hline Onça & $\begin{array}{l}\text { Hipparcus } \\
\text { Cassiopéia, Andrôme- } \\
\text { da e Perseu. }\end{array}$ & $\begin{array}{l}\text { Parte da Ursa } \\
\text { maior }\end{array}$ & Cetus & $\begin{array}{l}\text { Escorpião, } \\
\text { mas algu- } \\
\text { mas vezes } \\
\text { com partes } \\
\text { de Lupus } \\
\text { e Libra } \\
\text { acrescenta- } \\
\text { das como } \\
\text { patas }\end{array}$ & Cetus \\
\hline
\end{tabular}




\begin{tabular}{|c|c|c|c|c|c|}
\hline $\begin{array}{l}\text { Conjun- } \\
\text { to de } \\
\text { estrelas }\end{array}$ & Plêiades [no Touro] & $\begin{array}{l}\text { Constelação do } \\
\text { Cisne }\end{array}$ & Plêiades & Pleiades & $\begin{array}{l}\text { Plêiades } \\
\text { Menkar, } \\
\text { Pleiades }\end{array}$ \\
\hline $\begin{array}{l}\text { Jirau de } \\
\text { peixe }\end{array}$ & Hyades no Touro & $\begin{array}{l}\text { Cabeça da } \\
\text { constelação do } \\
\text { Touro }\end{array}$ & Columba & $\begin{array}{l}\text { O triân- } \\
\text { gulo de } \\
\text { Hyades }\end{array}$ & $\begin{array}{l}\text { Columba } \\
\text { Touro, Hiades }\end{array}$ \\
\hline $\begin{array}{l}\text { Cabo de } \\
\text { enxó }\end{array}$ & Órion & $\begin{array}{l}\text { Çinturão de } \\
\text { Orion }\end{array}$ & & $\begin{array}{l}\text { O cinto e a } \\
\text { espada de } \\
\text { Orion }\end{array}$ & $\begin{array}{l}\text { Orionis (Bella- } \\
\text { trix), Órion } \\
\text { (Cinturão e } \\
\text { Betelgeuse) }\end{array}$ \\
\hline Lontras & $\begin{array}{l}3 \text { estrelas não identi- } \\
\text { ficadas }\end{array}$ & $\begin{array}{l}\text { Planeta Vênus } \\
\text { ou Alfa do Cão } \\
\text { Maior. }\end{array}$ & $\begin{array}{l}\text { A cabeça do } \\
\text { Castor (A7) } \\
\text { nos Gêmeos } \\
\text { [Gemini]; o } \\
\text { Prokryon (A8) } \\
\text { na constelação } \\
\text { Pequeno Cão } \\
\text { [Canis minor], } \\
\text { o Sirius (A9) } \\
\text { na constelação } \\
\text { do Cão Gran- } \\
\text { de [Canis } \\
\text { major Rigel } \\
\text { (A10) no pé } \\
\text { esquerdo de } \\
\text { Orion, e o Al- } \\
\text { debaran (A12) } \\
\text { na constelação } \\
\text { de Touro[Tau- } \\
\text { rus] no grupo } \\
\text { das Hyades } \\
\text { Betegeuze, } \\
\text { uma estrela } \\
\text { vermelha } \\
\text { de primeira } \\
\text { grandeza situa- } \\
\text { da no ombro } \\
\text { direito de } \\
\text { Orion (A11). }\end{array}$ & $\begin{array}{l}\text { Sirius } \\
\text { (Canis } \\
\text { Major). } \\
\text { Cada uma } \\
\text { delas é } \\
\text { uma estrela } \\
\text { brilhante } \\
\text { que inclui } \\
\text { Procyon, } \\
\text { Castor, } \\
\text { Pollux, } \\
\text { e várias } \\
\text { outras além } \\
\text { de Sirius }\end{array}$ & $\begin{array}{l}\text { Estrelas em } \\
\text { Gemini, } \\
\text { Canis minor, } \\
\text { Canis Major, } \\
\text { Orion, Tau- } \\
\text { rus. } \\
\text { Crateris, } \\
\text { Corvus }\end{array}$ \\
\hline Garça & $\begin{array}{l}\text { Virgem e Cabeleira de } \\
\text { Berenice }\end{array}$ & & Corvo & & Corvo \\
\hline
\end{tabular}

Tabela 2. Constelações Tukano e área do céu correspondente registradas por diversos autores. 


\section{Constelações, movimentos e ciclos ${ }^{9}$}

Segundo Ñahuri \& Kumaro (2003:22), Umttkho Ñehktt (Avô do Universo) criou o mundo, dividindo-o em camadas, sustentando-o com seu bastão (lança-chocalho). Acima da camada terrestre está a Umutse pati (camada do céu) e abaixo a camada as águas: a Dia wiseri (maloca das águas) e o Wamt dia (rio de umari). Na explicação dos mais velhos o mundo, seguro pelo bastão, gira e faz rotações que fazem acontecer as diversas estações, invernos e verões. Os Tukano chamam um ciclo anual de kttmari, cuja tradução literal seria verões. Cada verão é chamado kuma ou wetiro, seca, em referência a vazante do rio. Cada inverno é chamado poero, cuja tradução aproximada é enchente, relativa a cheia do nível do rio. O ocaso das constelações, ou sua 'queda' no horizonte oeste é relacionado pelos Tukano com às chuvas e enchentes (Cabalzar 2010).

De acordo com José Azevedo (comunicação pessoal) “... a constelação nasce no horizonte leste, atravessa o céu, desce com a enchente, passa pelo rio de umari [situado no inframundo] e se transforma em Wai mahsã (Gente-peixe), até ressurgir no lugar onde aparece, como Ñohkoa diarã mahsã (Gente estrela real)". Segundo Hugh-Jones (1981:194-195) o fato de que a ascendência das estrelas parece parar as chuvas e sua descendência parece trazê-las tem a ver com as ideias relacionadas a Via Láctea e a um sistema fechado de circulação de água ao longo das três camadas do universo. No horizonte a abóboda do céu, comparado com as cabaças hemisféricas com interiores pretos esmaltados usados como recipiente de pó de coca, encontra a terra de modo que a Via Láctea, concebida como Rio de Leite do Céu é contínua com aquele da Terra. O leste, ou porta da água, é dita como sendo uma cachoeira que envia água para o mundo abaixo enquanto que a água que cai sobre as superfícies das montanhas de cume plano trazem água do mundo acima. Na terra os rios fluem de oeste para leste enquanto que os rios do céu e do inframundo fluem de oeste para leste. A água flui rio abaixo ao leste, onde é levada para o céu pela Via Láctea e trazida abaixo de novo no outro lado a oeste. Na medida em 
que as constelações sobem tomam água da terra para causar estação seca, e, quando elas descem de novo elas trazem água celestial como chuva. Via Láctea e chuva são mediadores entre domínios cósmicos e que aproximam os opostos.

A ocorrência de uma intensa chuva, e principalmente um forte estrondo do trovão, indicam que a constelação ou sua parte está se pondo, 'caindo' no horizonte oeste e marcam o início de um período de inverno, chuvas e enchentes. A associação do barulho do trovão com o ocaso das constelações é mencionada em certas narrativas Tukano, como na história de origem de Nohkoa Tero. De acordo com José Azevedo: "... Às vezes quando a constelação cai dá um barulho... tuuuu... lá para as sete, oito horas da noite por aí... pode cair e no outro dia começa a chover, uma hora da madrugada começa, chove, chove, chove, até meio dia e pára, isso se chama poero mesmo..." (Comunicação pessoal). Nesse sentido, Hugh-Jones (1979:228) afirma que na mitologia Barasana a tempestade e a chuva que marcam o momento em que a anaconda $\mathrm{He}$ (jurupari) come os iniciandos na história de origem das flautas sagradas, e o momento em que os Ayawa abrem a caixa da noite dada a eles por Yeba hakut na primeira catastrófica noite ${ }^{10}{ }^{11}$

Outro marcador da época de ocaso de algumas constelações é o aparecimento de certos pássaros, cujos nomes nesta época são acrescidos do termo buhkurã, (em Ramirez 1997:23, bikirã), cuja tradução é antigos, velhos, antepassados, mas o termo bthkttrã (bikttrãa, com melodia tonal alta) pode ser traduzido como pragas, insetos nocivos, ou parasitas de certo animal ou vegetal. (Ramirez 1997). Os pássaros Yai buhkurã, Nohkoa Tero buhkurã, e Aña buhkurã (pássaros não identificados), estão ao redor destas constelações e acompanham seu movimento.

De acordo com Uremiri José Azevedo (comunicação pessoal), seu pai Yupuri Feliciano Azevedo lhe contou:

"Naquela época no Umttkho Wikhã (Maloca do Universo) já existiam miriã porã mahsã (gente -pássaros): pihkoseã, baroa, uhpi miriã ${ }^{12}$, ñohkoa tero buthkurã, e yai buhkttã. Eles desceram de $\forall m$ ttkho Wikhã (Maloca do Céu) para o lago de leite, mas só os três primeiros con- 
seguiram se transformar em peixe e depois em ser humano. Os dois ficaram na camada dos peixes. Quando entraram na água se transformaram em peixe: ahkorõa (peixe água), seã pahkarã (piaba). Eles aparecem na época das enchentes de constelações Yai e Nohkoa Terõ e ficam piando. Oãkhtt fechou o buraco de transformação e eles ficaram para trás, não se transformaram em ser humano".

Suegu Manuel Azevedo, Tukano, clã Ñahuri porã (comunicação pessoal) correlaciona o estrondo do trovão ao momento de transformação destes pássaros em peixes:

"Quando é época da constelação Yai, os pássaros pretinhos Yai buhkurã aparecem. E a constelação está se pondo no horizonte de madrugada. Quando chegam as constelações há um barulho, que são as aves se transformando em peixes... A chuva começar a ocorrer lá pelas 9 horas da noite".

De modo análogo, Stephen Hugh-Jones (1981:185) afirma que na concepção Barasana, as estrelas realizam seu movimento de leste a oeste e retornam ao leste como bandos de pássaros migrantes cuja passagem corresponde ao ocaso helíaco (de certas constelações). As Plêiades retornam como Dolichonyx oryzivorous (triste pia); Cinturão de Órion e espada- como pequenos pássaros pretos que comem sementes, e outras constelações como Leucophoyx thula (garças brancas).

Os invernos/enchentes que ocorrem na época de ocaso de uma constelação, ou seja, quando ela está se pondo no horizonte oeste em determinado momento da noite ou madrugada, levam os nomes desta constelação ou da parte da constelação que está caindo, no caso de constelações segmentadas. Por exemplo, o inverno que ocorre na época de Mutã, é chamado, Mrthã poero (enchente de jacundá), o que ocorre na época em que Yai dtthpoa está se pondo é chamado Yai duthoa poero (enchente de cabeça de onça). Atualmente também são utilizados no cotidiano eventos do calendário cristão para definir os invernos, por exemplo, Yai poero (enchente de onça) também é chamada enchente da páscoa de Yai siõkhã poero (Estrela que ilumina a Onça), de enchente de domingo de Domingo de Ramos, Pamo oadutkã poero (enchente de osso de tatu), de enchente de natal. 
Dependendo da extensão da parte que está ‘caindo' o ocaso da constelação é associado com a ocorrência de um período de chuvas curto ou longo. As enchentes dos corpos da onça e da jararaca são associadas a longos períodos de chuva. Essas constelações segmentadas são as mais longas e seu ocaso dura mais tempo. Aña (jararaca), se põe entre setembro e dezembro, Yai (onça) entre março e abril, e Pamo entre dezembro e janeiro, e entre as suas partes ocorrem certos verões. Nos relatos de José Azevedo e Miguel Azevedo (comunicação pessoal) "para quem acompanha parece que uma constelação desce rápido, mas a passagem de uma constelação demora, pode durar dois meses, vem o verão e a caída dela é que ainda está acontecendo. Assim é com Yai e Aña...".

Os invernos são intercalados por verões curtos ou longos. Os verões mais longos são nomeados de acordo com fenômenos como os ciclos de determinada fruta, animal, ou seres, assim temos o merẽ kuma (verão de ingá), o urẽ kuma (verão de pupunha), o wamu kuma (verão de umari), o ñia kuma (verão de lagartas). Já os pequenos verões muitas vezes recebem o nome da constelação vigente. Os invernos e verões marcam a ocorrência de uma série de fenômenos ecológicos (variações no nível do rio, subida e piracema de peixes, floração, frutificação, revoada de saúvas, manivaras, subida de animais do mato), que por sua vez determinam a realização de atividades econômicas (roça, pesca, caça, coleta de frutas) e rituais (benzimentos feito pelos kumua para evitar doenças de cada época e festas cerimoniais) (ver Cabalzar 2010).

Vários grupos Tukano definem Plêiades como o mais impontante marcador temporal e atribuem a esta constelação nomes que significam algo como aglomerado de estrelas, ou coisa estrela, com exceção dos Kubeo que a denominam uchiwu (vespeiro) (Koch-Grünberg 2009 [1905]; Correa 1987). Koch-Grünberg afirma que "os indígenas [do Içana e Uaupés] marcam o tempo dos trabalhos de plantação pela posição das constelações de estrelas, especialmente de Plêiades. Quando estas desaparecem no horizonte, começa o tempo regular das chuvas fortes" (2005 [1909]: 530). Segundo Hugh-Jones (1981) Plêiades é a constelação mais importante do zodíaco Barasana e seu movimento 
no céu marca períodos importantes do ano. Plêiades, a mulher estrela, adquire diversos significados na cosmologia, contraparte noturna do Sol, cuia de cera (sua vagina), mulher xamã, e controla as estações e a agricultura. Conforme Correa (1987) entre os Kubeo os principais rituais de iniciação ocorrem na época de Camarão e do Vespeiro (Plêiades). Gerard-Dolmatoff (1997:265-266) afirma que, para os Desana, as Plêiades, identificadas com ramos de frutas, se elevam em direção ao oriente no firmamento depois do ocaso no final de setembro e se põem antes da aurora no final de março, anunciando em ambos os casos o começo das principais temporadas de frutificação, da migração dos peixes, e o tempo propício para os rituais de iniciação (Epps \& Oliveira 2013:104-105). Aeitu (2005) afirma que para os Tuyuka:

"O ano é definido pelo ciclo da grande constelação das Plêiades (ñokoatero). Quando ela aponta no nascente de madrugada é sinal de ano novo. Neste período as madrugadas têm um nevoeiro frio (yttsttare), é tempo de iniciação masculina, coincidindo aproximadamente com o mês de julho. $\mathrm{O}$ ano, começa portanto, com o fim das enchentes (em geral segunda metade de julho). Entre dezembro e fevereiro, quando Nokoatero aparece ao anoitecer mais no centro do céu é tempo para fazer roça de mandioca, [...] época de fazer proteção contra doenças, das cerimônias para amansar yukumasã (gente árvore). Quando ñokoatero $[. .$.$] ao anoitecer está na posição das quatro horas da tarde no$ céu, já começa a chover mais. Na época que antecede a feitura das roças, o benzedor faz cerimônia de proteção, para evitar chegada de doenças ou acidentes de trabalho na roça. No término de fazer roçado, época de verões fortes, são realizadas danças para que ocorra um bom verão para queimar roças" (Aeittt 2005:150).

\section{Imagens das constelações na mitologia Tukano.}

As histórias de origem de constelações não consistem por si só tema de narrativas mitológicas, mas se encontram diluídas em histórias que narram eventos ocorridos na época de Bahuari Mahsã (Gente do Aparecimento), primeira humanidade- que desceu da Maloca do céu para este mundo para desenvolver seus trabalhos e criar as condições para que a humanidade atual aqui vivesse. Numa época em que 
não havia a divisão nítida entre grupos étnicos e clãs e, portanto, nem regras de parentesco e de casamento bem estabelecidas, as narrativas relativas à vida destes personagens muitas vezes falam de seus casamentos com mulheres não humanas (estrela, filhas cobra, etc) que fracassaram por motivos diversos (morte das esposas, incompatibilidade entre modo de vida da esposa e do esposo) e de personagens que por descumprirem regras de comportamento foram lançados ao céu (Epps \& Oliveira 2013:104-105). Existem iniciativas de registro específico de histórias de origem das constelações, como o Volume 8 da Coleção Narradores Indigenas, publicada pelos Desana Diakuru \& Kisibi (2006) e a revista publicada pelos Tukano e Desana, Aeity \& Acimet (2008).

Neste tópico utilizarei como narrativas-base histórias da Gente do aparecimento contidas no livro Mitologia Sagrada dos Hausirõ porã (Ñahuri \& Kumaro 2003), procurando demonstrar como as histórias de origem das constelações registradas em Aeity \& Acimet (2008) e Diakuru \& Kisibi (2006), estão relacionadas com as primeiras. Agruparei as constelações pelo modo como elas se articulam em narrativas mitológicas comuns, buscando apontar os significados que elas adquirem ao longo destas narrativas e como dentre estes diversos significados prevalecem aqueles relativos ao contexto ritual. Veremos que as versões podem variar de acordo com o clã, ou o povo do narrador e poderemos nos surpreender com a equivalência entre versões provenientes de narradores distantes geograficamente ou culturalmente.

\section{As filhas de Buhpo (Trovão)}

A origem das constelações Aña (Jararaca) e Sio Yahpu (Cabo de Enxó), compõem a narrativa sobre a vingança de Yepa Oahku (ou Yepa Muhipu, o Lua, demiurgo Tukano) contra Buhpo (Trovão) e suas filhas Aña Mahsã (Gente Jararaca). Na história narrada por Yupuri Feliciano Azevedo, Tukano, clã Ñahuri porã, em Ñahuri e Kumarõ (2003:5359), Yepa Oakhu vivia na sua casa yohkoãdiakawi (Casa das estrelas). Todo dia via o reflexo da constelação Sio Yahpu e havia uma estrela que era a mais bonita. Um dia ela apareceu fisicamente e ele casou 
com ela. Butpo tinha inveja de Oakhu pelo fato deste não querer se casar com suas filhas, Aña mahsã (Gente Jararaca), e convidou-o para ir a um caxiri com intuito de matar sua esposa. A esposa não foi à festa, mas foi morta por uma cobra dentro do matapi no porto. Yepa Oakhu sabendo disso, pegou um yuhtasero (faixa utilizada pelos homens abaixo do joelho em rituais) ${ }^{13}$ dos dançarinos e colocou dois dentes de cobra, 'benzeu-os' deixando como cabeça de jararaca e com corda fez o corpo da jararaca. Fez outro benzimento, jogou no centro da roda de dança e a jararaca mordeu o velho Buhpo (Trovão), que morreu. Ao chegar em casa, Oakhu viu sua esposa morta transformada em peixe pirarara e seu filho transformado em pássaro. Decidiu voltar para buscar seu irmão, mas a filha de Buhpo já o havia matado. Chegando lá foi convidado pela mesma para ir tomar banho no porto. Ela estava tecendo yuhtasero e tentou matá-lo transformando um toco de pau em diakahta aña (tipo de jararaca). Yepa Oakhu cortou a cabeça da jararaca com Sio yahpu (Cabo de Enxó). Era o irmão maior dela. Saiu mais uma cobra de dentro do pau oco e Yepa Oakhu decepou sua cabeça. Era o irmão menor dela. Então benzeu o coração de seu irmão para fazê-lo voltar à vida e transformou-o em um grande gavião, que treinou para carregar paus pesados até o alto e depois soltá-los. Em seguida transformou-o em um pequeno filhote e levou-o para a roça das filhas do Trovão, que gostaram dele e quiseram criá-lo. Mas o pássaro era amaldiçoado e benzido para fazer maldade e se transformou em um grande gavião que agarrou Buhpo na coluna vertebral, levando-o para o alto e deixando cair no chão, que Oakhtt tinha soprado e transformado em todos os tipos de pedra. Buthpo atingiu o chão e só sobrou sangue. Assim, vingou-se de todos da família do Buthpo, que também era considerada Aña Mahsã.

Mas, é apenas em outra versão que Uremiri Aprígio Azevedo e Ahkuto Mariano Azevedo, clã Ñahuri porã, explicam que "[...] Yepa Oakhu corta a jararaca com Sio Yahpu (cabo de enxó), e ela é lançada ao céu, transformando-se na constelação de Aña (Jararaca)" (Acimet \& Aeity 2008). 
Diakuru \& Kisibi (2006), Desana, clã Wahari Diputiro porã, articulam as histórias das constelações Jararaca e Cabo de enxó em uma narrativa idêntica. A constelação Aña surge através da vingança realizada pelo demiurgo Deyubari Goãmu por seus cunhados neká masã (gente estrela) terem matado sua esposa fazendo-a ser engolida pelo matapi enquanto recolhia peixes. Durante a festa Deyubari Goãmu tirou as cordas dos pelos de onça e de macacos presa nos ornamentos de cabeça e com ela formou o corpo de uma cobra jararaca. Com seu waituru (enfeite de canela) fez a cabeça da jararaca, com fio de tucum formou o dente da cobra e com o caapi fez o veneno dela. Enrolou a jararaca no yegu (cetro-maracá) e com ele tocou o pé do segundo e do terceiro bayá (mestres de dança) para a cobra mordê-los. O segundo bayá morreu na hora, o terceiro foi salvo com orações e remédio do mato. Durante a viagem de volta pegou a jararaca que carregava nas costas e jogou para longe. Quando ele estava dançando na maloca de Gente-estrela a corda ficou toda banhada de suor, por isso ela se transformou em chuva (inverno) .

Ao narrar a história de origem da constelação Yohoka duhpu (cabo de enxó) esclarecem que o grupo de gente estrela morava nessa constelação e que quando Deyubari Goãmu foi a uma festa pedir licença para os pais de sua esposa por ter "se amigado com ela", ouviu falar da morte de sua esposa. Yohoka duhpu indicava a posição dos dançarinos durante as danças de gapiwaya. Os baya foram mortos pelo demiurgo e o sangue, o suor, as lágrimas e caxiris transformaram-se em chuva (Diakuru \& Kisibi 2006:33-34), que ocorre na época de ocaso desta constelação.

A versão Barasana da história da constelação de cabo de enxó registrada por Hugh-Jones (1979 - tradução nossa), também menciona a ocorrência de mordida de cobra em uma linha de dança ritual:

"Quando Oa Suna, povo Tatuyo mucura, viu He [flauta jurupari] pela primeira vez haviam três homens alinhados (as três estrelas do cinto de Orion). O homem do meio foi mordido na perna por uma cobra. É por isso que a estrela do meio é menor que as 
outras duas. A perna do homem se tornou torta e paralizada e se tornou o enxó cerimonial que os Tatuyo usam nos seus ombros durante as danças, chamado enxó de dança (basa sioro)" (HughJones 1979:145).

Segundo Hugh-Jones (1979), estas enxós, que consistiam originalmente em instrumentos para trabalhar madeira, também eram utilizados como ornamentos de dança durante ritos com jurupari entre os Tukano, Tariana, Bará e Tatuyo, situações em que eram alocados sobre o ombro esquerdo de chefes, xamãs e principais dançarinos. O autor afirma que apesar de Koch-Grünberg (1909-1910, vol I) e Bruzzi da Silva (1962) fazerem referência a este instrumento e do último registrar uma constelação chamada Cabo de enxó, nenhum dos dois relacionou diretamente a enxó cerimonial com a constelação. Ao narrarem a criação do mundo, os Tukano, Nahuri $\&$ Kumaro, afirmam que "Sio Yahpu, cabo de enxó, era o poder que Umukho Nehku (Avô do Universo) possuía na maloca Yepa Wikhã. Era defesa contra inimigo, servia como uma arma" e complementam "...Hoje em dia, geralmente só os pajés ou baya usam nos cerimonais" (2003:21). Para José Azevedo (comunicação pessoal) "O cabo de enxó era utilizado pela primeira humanidade para fazer guerra contra espíritos e matar seus inimigos e como era muito importante ficou no céu para ser respeitada”. Segundo Jovino Pedrosa, clã Ñahuri porã, (comunicação pessoal para Aloisio Cabalzar) “... um dos petróglifos da cachoeira Tukano [situada na divisa entre o trecho baixo e médio do rio Tiquié] é a representação do cabo de enxó, que eram armas que as mulheres usavam para se defender de homens que queriam desvirginá-las”. De acordo com Guilherme Azevedo (comunicação pessoal), durante a viagem de transformação da humanidade, ao chegar em um determinado ponto, a Gente da transformação encontrou uma barreira intransponível. Doetiro, demiurgo que liderava a viagem, retornou até a maloca do céu para pedir ao Avô do Universo o cabo de enxó, que ele havia esquecido. Ao recebê-lo colocou-o no ombro e desceu. Este cabo de enxó soltava raios e ao 
utilizá-lo Doetiro conseguiu abrir espaço para a gente de transformação prosseguir viagem.

\section{Origem das flautas sagradas}

As narrativas Tukano e Desana de origem das constelações Pamo (Tatu), Dahsitt(Camarãoł e Muhã (Jacundá), narradas em Aeity \& Acimet (2008); Diakuru e Kisibi (2006) e Cardoso (2007), se entrelaçam de diferentes maneiras com a história de origem e roubo, por parte das mulheres, das flautas de jurupari, utilizadas em rituais de iniciação masculina e dabucuris (ritos de ofertas entre cunhados) e interditas às mulheres. Na versão do clã Hausirõ porã registrada em Ñahuri \& Kumarõ (2003) quando Bisiu subiu ao universo após ser queimado levou consigo o jurupari que era seu corpo. Das cinzas de seu corpo surgiu uma planta paxiúba. As filhas do líder Yepa mahsã encontraram esse pé e pediram para o pai tirar paxiúba para fazer cumatá. $\bigcirc$ pai viu que o pé era diferente e a partir dessa planta confeccionou flautas jurupari e entregou apenas um pedaço de paxiúba para as mulheres. Em seguida, passou recomendações a seu filho caçula para ir de madrugada ao porto, vomitar com cipó e aprender a tocar as flautas. As mulheres ouviram e foram lá, vomitaram, encontraram estas flautas, tomaramnas e obrigaram o Mutha (jacundá) a ensiná-las a tocar, tornando-se as chefes do universo. Os homens ficaram responsáveis pelos trabalhos anteriormente realizados pelas mulheres: iam a roça, ralavam mandioca, preparavam caxiri. As mulheres não souberam tomar conta do universo, faziam as festas com jurupari em qualquer momento, e não apenas na estação que tem mais frutas e na época de iniciação masculina. Os homens decidiram retomar o jurupari das mulheres quando estas faziam uma festa de dabucuri com jurupari. Para isso fizeram flautas com som forte que levaram-nas a desmaiar. Estando desmaiada, a primeira, Mãe das flautas sagradas, tentou enfiar na vagina a flauta principal. Duhigó fugiu pela porta do poente. Yupako arrastou-se na direção do nascente, onde é conhecida como dona das roupas no Lago de Leite. A terceira arrastou-se para o norte. Mais uma vez os 
homens conquistaram seus poderes e continuaram a ser os donos do universo.

Nesta narrativa Mutha (Jacundá) é o único ser que alude ao nome de uma constelação. É nas narrativas de origem de constelações registradas em Aeity \& Acimet (2008 - tradução Damásio Azevedo), que Armando Macedo, Desana, clã Toa piarã, esclarece que "Pamo, o tatu, era o jurupari das mulheres, que tinha a forma deste animal" e que Maximiano Aguiar Desana, clã Yugt Wirã, afirma que Mutha e Dahsitt, eram Miriã porã mahsã (gente de jurupari), responsáveis pelos principais toques de jurupari. Os dois tiveram uma inimizade e o camarão fugiu, indo morar nos paus ocos. O jacundá não parou de persegui-lo, então o camarão fugiu para o universo, até o céu. Quando visualizamos as constelações elas estão juntas no céu. Os dois são Ome mahsã (Gente nuvem), responsáveis pelos nevoeiros e neblinas.

Na versão Desana de Diakuru \& Kisibi (2006), clã Wahari Diputiro porã, o camarão foi o primeiro incumbido pelos Umuri masá (Gente do Universo) a cuidar das flautas sagradas, mantendo-as limpas, mas não conseguiu cumprir sua obrigação. Os Umuri masá jogaram-no para o alto, para morrer seco e por isso hoje ele está no céu. As gotas de água que saíram do corpo do camarão transformaram-se em chuva, de modo que o camarão indica uma estação do ano, uma enchente. Quando o camarão morreu o jacundá assumiu seu cargo e ensinou as mulheres a tocarem as flautas. Os Umuri masá não gostaram e jogaram -no para fora das flautas sagradas, empurrando-o para o alto ao lado do camarão, como lembrança do fato de que os dois são traidores. Quando os Umuri masá os tiraram de dentro das flautas sagradas, a água das flautas transformou-se numa enchente. Pamo, constelação do Tatu, está situada numa narrativa diferente. O osso do tatu foi utilizado pelos Umuri masá como botão para ajustar na cabeça a corda de pêlos de macacos. $O$ tatu fugiu indo para o universo, mas eles o perseguiram e o alcançaram. É onde está hoje a constelação. Depois de agarrá-lo, o esquartejaram para tirar seus ossos, jogaram fora o espinhaço, e regressaram para o seu sítio, deixando lá o espinhaço e o 
casco do tatu. No céu pode-se ver o osso do espinhaço, e logo após, o casco do tatu. O sangue do tatu se transformou em chuva.

A associação entre flautas sagradas e constelações também está presente entre os Kubeo. De acordo com Correa (1987:152-153), a partir das cinzas de um ser denominado Wamudama surgiram palmas de paxiúba e ramos de ingá que chegavam até o céu. Yurijerí utilizou seu andaime (jirau) e sua enxó para subir nas palmas e fazer as flautas e trompetes. Estas flautas e trompetes ancestrais ficaram no céu como constelações associadas aos objetos utilizados para a sua confecção, além de outros objetos usados pelos antigos. As mulheres roubaram as flautas e não souberam utilizá-las, faziam dabucuris de qualquer coisa. Os homens as retomaram e Yurijerí as fez pagar com a vida. Por isso hoje as mulheres não podem ver as flautas e não se explica o significado das constelações no firmamento.

\section{História dos Diroa e Yaiwa (Gente Onça)}

A origem das constelações Yai (Onça) e Wai Kahsa (Jirau de Peixe) é mencionada por alguns conhecedores Tukano na longa narrativa da história de vida do demiurgo Buhtuiari Oakhut, que inclui as desavenças entre os Diroa, personagens trickster da mitologia Tukano, e os Yaiwa (Gente Onça).

Buhtuiari Oakhtt passou um tempo longe de casa e ao retornar encontrou apenas seus avós, pois todos seus outros irmãos maiores e parentes haviam sido devorados pela Gente Onça. Ele também foi morto e devorado pelas Onças durante uma caçaria. Seu avô se transformou em caba e conseguiu pegar um pedaço de seu coração e jogá-lo. Ao cair numa cachoeira se transformou em dois peixes diroa kurubisa. Ao serem queimados pela avó junto aos potes de cerâmica, esses dois peixes se transformaram em dois meninos, que eram os dois Diroa. A avó contou como haviam morrido seus parentes e eles decidiram vingar-se. Com zarabatana e curare da maloca do céu, foram ao mato e encontraram pássaros que se transformaram em onças. Os Diroa lhes rasgaram as bocas, arrancaram os dentes, transformaram-se em broca 
e furavam os dentes para fazer colares de dente de onça com cipó. Este foi o início dos ornamentos de dança do baya, dos colares e cintos de dente de onça e enfeites de penas e plumas ${ }^{14}$. A avó dos Diroa era neta das onças e por isso estranhava o que eles faziam. Certo dia a avó onça disse a seu marido que seus parentes estavam precisando de balaios e tipitis, cumatás e peneiras. Os Diroa, acompanharam-nos na viagem até a Maloca das Onças e disseram ao velho para ele fazer um dabucuri de balaios. O velho disse que seria bom juntar com peixe. Os Diroa cortaram a cabeça da cobra-tucunaré (Bu-pirõ) com cabo de enxó e transformam o corpo dela em vários tipos de peixes que 'estragaram com sopro'. Quando voltaram ao tapiri de pesca o seu avô havia preparado um jirau muito pequeno para a quantidade de peixes que eles haviam conseguido. Por isso preparam outro jirau com paus e cipós 'estragados'. Buscaram lenhas 'estragadas', para moquear os peixes. Foram até a Maloca do céu pedir ao Trovão o poder de lançar raios e roubaram os raios mais fortes que estavam nas pontas dos supercílios do trovão. No dia do dabucuri na maloca da Gente Onça foram recebidos, ofereceram peixes para as onças e começaram a dança do kahpiwaia. Ornamentaram-se com penas de pássaro e dentes de onça que já haviam matado. Como haviam se multiplicado, as onças não conseguiam saber quem eram os Diroa. Os Diroa entoaram a dança dos inimigos até a hora de tomar caapi. As onças queriam matá-los durante a embriaguês do caapi, mas eles bebiam rápido e não tinham reação. Disseram às onças que só poderiam devorá-los depois de terem terminado a última parte do canto. Saíram da maloca fizeram com tipitis cobras e espíritos devoradores para comerem as onças que tentassem fugir. Voltaram para maloca, disseram seu nome. Quando terminaram a dança as onças pularam em cima deles e morderam, mas não conseguiram devorá-los. Os Diroa cobriram sua avó com bacia de tuiuca, saíram para fora com o avô-caba e lançaram raios de trovão. Dentro da maloca só havia sangue. Fizeram reza para trazer de volta à vida sua avó, mas ela se recuperou junto com as outras onças. Novamente lançaram raios, e acabaram com todos, inclusive com sua 
avó. A maloca se incendiou. Continuaram dançando a noite inteira e na manhã seguinte subiram para a maloca do céu com seu avô (Ñahuri \& Kumarõ 2003).

Na versão de origem destas constelações registrada em Aeity \& Acimet (2008), Feliciano Azevedo, clã Nahuri Porã, apresenta uma narrativa semelhante e explica que o jirau feito pelo velho é "como o que gente vê no universo e chama-se Wai kahsa" e que "o sangue das onças, que eram chefes, de tanta força que tinha, espalhou-se e subiu para o céu.... por isso Yai está no céu agora....”. Na versão dos Desana Diakuru \& Seribhi (2006), os Umuri masã (Gente do Universo) estavam procurando dentes de animais para completar os enfeites de dança dos gapiwaya-cintos, as cordas, e os colares e um dia, encontraram uma onça, agarraram, mataram, arrancaram-lhe os pêlos e os dentes. Jogaram o corpo dela bem longe, para ninguém saber o que eles haviam feito com ela, mas os parentes da onça morta o descobriram e desde então ficaram inimigos dos Umuri masã. A saliva e o sangue da onça transformaram-se em chuva.

\section{Nohkoa Tero}

$\mathrm{Na}$ narrativa do Desana Maximiano Aguiar, registrada em Aeity \& Acimet (2008 tradução Cornélio Lobo, Desana, clã Yugu Wirã), a origem de Ñohkoa Tero (Conjunto de Estrelas) está relacionada à história de um homem que estava fazendo um cacuri, antes da enchente, quando chega outro homem que pergunta o que ele está fazendo e diz para que faça seu trabalho porque a enchente de nuvens (ome poero) já iria chegar, e a constelação viria caindo a meia noite. O homem percebeu que ele era Nohkoa diarã mahsã (Gente Estrela Real). Quando o homem virou de costas viu que havia nas costas do homem-estrela uma constelação, Nohkoa tero. A meia noite zoou um barulho, então começou chuva, vento e trovoada, amanheceu chovendo e continuou a chover o dia inteiro, durante a noite e só parou no outro dia ao meio dia. Estava acontecendo a principal constelação. Por isso a constelação Nohkoa Tero ficou no universo, ela estava nas costas do homem estrela. 
Na tradução de Hausirõ Vicente Azevedo, Tukano, clã Nahuri porã desta narrativa (comunicação pessoal), o que aparece nas costas do homem- estrela é um 'escudo bem brilhoso', como os utilizados pelos antigos Tukano em guerras intertribais e em contexto ritual (KochGrünberg 2005 [1907]). De acordo com Roberval Pedrosa, Tukano clã Nahuri porã (comunicação pessoal), um velho Miriti Tapuia lhe contou que os colares de prata com motivo momõro (borboleta) utilizados nas danças pelos antigos eram chamados Ñohkoa tero.

A história acima remete à narrativa Curripaco (Arawak) apresentada por Rojas (1997:139) sobre a constelação Waliperi, que está boca acima, dando-nos as costas, e levando sobre ela nove pequenas estrelas, que são brilhantes passarinhos: as plêiades. Um dia Waliperi se encontrou com as gentes que estavam preparando armadilhas de pesca e diziam que tinham que prepará-las antes que baixasse o passarinho brilhoso. Waliperi escutou e disse a eles que esperassem cinco dias, que então viria o tempo de sua crescente e pediu que eles instalassem as armadilhas porque esta seria muito forte. Mostrou moquéns para eles aprenderem a fabricá-los. Despediu-se da gente que estava instalando armadilhas. Andou por aí e as pessoas perguntaram o que ele fazia. Ele disse que procurava frutas e timbó para tinguijar nos igarapés. Levava uma forquilha, a cobra amarela, e um gancho em que amarrava a erva. Tinguijava.

Uma das possíveis traduções para Nohkoa tero é tempo de estrelas ou tempo de constelações. Conforme vimos, todas as constelações estão relacionadas a períodos de inverno, porém Ñohkoa Tero, Wai Kahsa e Sio Yahpu, de acordo com vários conhecedores do médio Tiquié (comunicação pessoal), são consideradas constelações frias, cujo ocaso antecede o tempo frio de Aru (Wuru). Em certas encantações o especialista xamânico busca nestas constelações e em Boreakã (Vênus) e Wuru (Preguiça), ser relacionado à 'friagem', o frio para resfriar o calor do fogo e do sol, que são considerados nocivos à saúde (Aeitypp 2010). Rojas entre os Curripaco, fala das estrelas frias, dukumenai, cujo chefe é Waliwa, estrela da manhã. Às estrelas 
frias se refere como um "Lugar frío donde los payés piden que se enfríe um enfermo” (1997:71).

Os Desana Diakuru \& Kisibi (2006), relacionam a origem desta constelação a uma vingança feita pelos neka masá (Gente estrela), com a constelação Sio Yahpu (cabo de enxó) no começo do mundo. Abe (sol) queria que os neká masá que apareceram junto com eles fossem considerados como os irmãos supremos dos Umurĩ masá, mas estes últimos, que saíram da Cuia de transformação, não aceitaram. Eles queriam que eles fossem seus servos. Nekamu (líder supremo das estrelas), casou com Bupu Mago (filha do Trovão), que o matou. Com sua morte seus irmãos ficaram servos dos Umuri mahsá. Os filhos de Umurĩ e dos Neká masá não se davam bem. Um dia, os filhos dos líderes e dos servos inventaram um tipo de brinquedo feito com a fibra enrolada de folha de buriti. Eles abusavam deste jogo, fazendo os filhos dos servos chorarem. O líder dos neká masá chamou o seu filho para enrolar o fio, transformando, por meio de uma oração, o novelo numa pedra e mandou lançá-lo contra o filho mais atrevido dos Umurĩ masá. Este o lançou na direção das costas dele. A bola de fio penetrou bem nas costas saindo do umbigo e o menino morreu na hora. Os Neká masá saíram da maloca dos líderes dos Umuri masá e foram para um lugar distante. Para impedir os Umurĩ masá de persegui-los, fizeram cair muita chuva. As mulheres e as crianças choravam, com medo de que os líderes matassem a todos. Cada grupo de Neká masá escolheu um lugar próprio para morar. Um deles foi na constelação yohoka dupu (Cabo de enxó). A constelação Nekaturu recorda o momento em que os neká masá se amontoaram para fazer sua guerra de independência dos líderes da Gente do universo. As lágrimas das mulheres e das crianças transformaram-se em chuva.

Apesar de esta versão parecer totalmente diversa das versões apresentadas acima, há um ponto em comum, em todas elas atribui-se destaque às costas de um personagem: na primeira e na segunda um homem possui a constelação de Ñohkoa Tero nas suas costas, na terceira, o filho de Neká masã acerta um brinquedo nas costas do filho do 
inimigo. Koch-Grünberg (2009 [1905]:270) registrou entre as crianças do rio Tiquié uma brincadeira feita de fios semelhante à citada acima e entre os desenhos compostos está um denominado Plêiades.

\section{Origem dos ornamentos de dança:}

Versões Desana da origem da constelação de Yhe (Garça), estão relacionadas à origem dos ornamentos plumários de dança. Maximiano Aguiar, Desana, clã Yugu Wirã, narra em Acimet \& Aeity (2008) que a Gente do Aparecimento estava procurando nos pássaros do mundo inteiro penas para fazer enfeites, mas só achava penas impróprias. Um dia caiu no mundo uma pena que parecia algodão, pena de pássaro branco, e então quiseram descobrir de que pássaro era aquela pena. Procuraram no mundo todo, encontraram a garça e a depenaram, na barriga e nas asas. Assim conseguiram enfeites. Ela não conseguiu mais voar. $\mathrm{O}$ depenado ficou no mundo inteiro e hoje está na camada do céu, é Ñohkoa diro mahsu (gente de carne de estrelas) e Omepoe mah$s \pi$ (gente de enchente de nuvens).

Na versão Desana (clã Wahari diputiro porã) registrada em Diakuru \& Kisibi:

"A constelação de Garça foi criada pelos Pamttri masá nos primeiros dias de sua vida. Eles estavam fabricando os enfeites de dança que usam nos gapiwaya, quando se deram conta de que as penas dos pássaros eram os melhores enfeites para esse tipo de dança porque elas demoram a estragar. Um dia, elesagarraram uma garça e mataram para depená-la. Depois de terem arrancado as suas penas, a jogaram na $U$ mttsi Patore. Em seguida, eles estenderam as penas próximo ao lugar onde eles as tinham arrancado, para eles secarem. A garça que eles mataram era karẽ yahi (garça de abiu), a mais bonita de todas, considerada como o rei das garças” (Diakuru \& Kisibi 2006:18-19).

Por isso, chorando pelo que fizeram com ela, seus irmãos decidiram que ela não desapareceria como qualquer um. Transformaram o derrame de sangue numa chuva para relembrar a primeira morte dos seres vivos depois da criação do mundo, fazendo também o corpo dela ficar bem no centro do universo, para recordar o fato de que ela era o rei das garças. 
Entre grupos Tukano, as penas de garça são utilizadas para confeccionar adornos cerimoniais. O pente de penas de garça é feito com penas de mutum e de garça, que são fixadas sobre um corpo feito de curaúa sobre arumã. As penas utilizadas devem ser aquelas que ficam acima do rabo e para as plumagens são utilizadas penas de garça maiores. Para as asas de garça matam a garça, tiram as asas e secam ao sol. Elas são guardadas na caixa de adornos e nas festas são assentados junto a outros adornos através de um talo de bananeira nas costas do dançador (Aeitu 2005:169-171).

A partir das versões apresentadas é possível delinear uma tabela relacionando as histórias de origem das constelações às narrativas da Gente do Aparecimento, com exceção de Ñohkoa Tero, constelação fundamental, que aparece em uma narrativa isolada:

\begin{tabular}{|l|l|l|l|l|}
\hline $\begin{array}{l}\text { Narrativas da } \\
\text { Gente do Apareci- } \\
\text { mento }\end{array}$ & $\begin{array}{l}\text { As filhas Buth- } \\
\text { po (Trovão) }\end{array}$ & $\begin{array}{l}\text { História dos Diroa } \\
\text { e Yaiwa }\end{array}$ & $\begin{array}{l}\text { Origem das } \\
\text { flautas sagradas }\end{array}$ & $\begin{array}{l}\text { Origem dos orna- } \\
\text { mentos de dança }\end{array}$ \\
\hline $\begin{array}{l}\text { Origem das Cons- } \\
\text { telações }\end{array}$ & $\begin{array}{l}\text { Aña } \\
\text { Sio Yahpu }\end{array}$ & $\begin{array}{l}\text { Yai } \\
\text { Wai kahsa }\end{array}$ & $\begin{array}{l}\text { Dahsitt } \\
\text { Mutha } \\
\text { Pamo }\end{array}$ & Yhe \\
\hline
\end{tabular}

Tabela 3. Narrativas da Gente do Aparecimento e histórias de origem de constelações associadas.

Portanto, podemos afirmar que o céu Tukano é povoado por diversos personagens e objetos da época da Gente do Aparecimento. Como bem sintetizou o Uremiri José Azevedo:

"As constelações são os instrumentos que a gente do Aparecimento teve. A jararaca é o filho do Trovão, o tatu é flauta sagrada, o jacundá também. $\mathrm{O}$ camarão servia para limpeza da maloca da gente de Aparecimento. O Onça era chefe do paricá e de virar pajé e kumu, 
por isso ficou um pouco afastado das outras constelações. Meu finado pai Feliciano viu esse tipo de colar feito de miçanga que é Nohkoa Tero. O que tem aqui é cópia de lá. O cabo de enxó era arma que usava no pescoço com corda, para luta que tiveram lá em cima. O jirau de peixé foi utilizado pelos Diroa. É na linha de transformação, Nohkoa diarada, linha de estrelas, que estão estes instrumentos. Quando vieram para cá, deixaram tudo..." (Comunicação pessoal, tradução de Dario Azevedo).

Conforme pudemos observar a partir das histórias apresentadas, as constelações não possuem um significado único ou fixo e podem corresponder a múltiplas imagens de acordo com diferentes versões de histórias ou ao longo de uma narrativa. Uma leitura possível de se fazer das histórias de origem das constelações e que detém inegavelmente uma riqueza ímpar em termos estéticos e cosmológicos, é privilegiar, dentre as imagens e significados, aqueles relativos ao contexto ritual, conforme a tabela resumo:

\begin{tabular}{|c|c|c|}
\hline Constelação & Contexto ritual & Imagens e significados \\
\hline Sio Yahpu & $\begin{array}{l}\text { Dança de } \\
\text { kahpiwaia } \\
\text { (Linha de dança) }\end{array}$ & $\begin{array}{l}\text { Yuhtasero/ Waiuturu (enfeite usado na perna)- cabeça da } \\
\text { jararaca } \\
\text { Fio de tucum- dente da cobra } \\
\text { Kahpi (bebida ritual feita a base de Banisteriopsis caapi)-vene- } \\
\text { no da cobra } \\
\text { Gente jararaca- irmão maior, irmão menor, pai } \\
\text { Corda de pêlos de macaco e onça- corpo da jararaca) } \\
\text { Instrumento usado por Oakht para cortar cabeça das jara- } \\
\text { racas } \\
\text { Arma usada pelos demiurgos } \\
\text { Instrumento ritual } \\
\text { Linha que indica a posição dos baya durante danças de } \\
\text { gapiwaya }\end{array}$ \\
\hline $\begin{array}{l}\text { Pamo } \\
\text { Dahsitt } \\
\text { Mttha }\end{array}$ & $\begin{array}{l}\text { Dabucuri com } \\
\text { jurupari }\end{array}$ & $\begin{array}{l}\text { Flauta jurupari das mulheres } \\
\text { Botão utilizado na cabeça para ajustar a corda de pelos de } \\
\text { macaco } \\
1^{\circ} \text { responsável por tomar conta das flautas sagradas } \\
2^{\circ} \text { responsável por tomar conta das flautas sagradas } \\
\text { Ensinou o toque do jurupari às mulheres } \\
\text { Flauta sagrada }\end{array}$ \\
\hline
\end{tabular}




\begin{tabular}{|l|l|l|}
\hline Yai & $\begin{array}{l}\text { Dabucuri de } \\
\text { peixes } \\
\text { Com } \\
\text { kahpiwaia }\end{array}$ & $\begin{array}{l}\text { Utilizados na confecção do cinto de dente de onça } \\
\text { Gente onça } \\
\text { Chefe de paricá } \\
\text { Jirau utilizado para moquear oferta ritual }\end{array}$ \\
\hline Nohkoa Tero & - & $\begin{array}{l}\text { Gente estrela } \\
\text { Adorno de prata } \\
\text { Escudo de guerra e ritual }\end{array}$ \\
\hline Yhe & $\begin{array}{l}\text { Dança de } \\
\text { Kahpiwaia } \\
\text { (pré-ritual: } \\
\text { confecção de } \\
\text { adornos de dança) }\end{array}$ & $\begin{array}{l}\text { Penas usadas para confeccionar adornos cerimoniais } \\
\text { Garça real }\end{array}$ \\
\hline
\end{tabular}

Tabela 4. Múltiplas imagens das constelações Tukano: predominância dos significados rituais.

Nesse sentido, é interessante retomar a noção de siõkha, estrelas que ficam à frente das constelações, e que no relato de $\forall$ remiri José Azevedo representam os 'irmãos chefes' responsáveis por guardar ornamentos cerimoniais, que estão dentro das constelações.

Há uma narrativa sobre a origem da noite que demonstra mais claramente que um dos modos de se compreender a correlação entre constelações, contexto ritual, adornos cerimoniais, é a atentar ao fato de que, conforme já apontado por Hugh-Jones (2014 e 2015) para os Tukano, a caixa da noite pode ser concebida como uma caixa de adornos cerimoniais. Neste mito os irmãos-chefe, correlacionados anteriormente aos siõkhã, desempenham papel fundamental. Isto fica evidente na versão de Miguel Azevedo (Ñahuri \& Kumaro 2003:188191), na qual os Pamuri mahsã viviam na casa do Rio de Leite e não tinham a divisão do tempo em dia e noite. Por isso foram até a Namiriwi (Casa da Noite) pedir ao Dono da noite (Namirisota) a caixa da noite, que consistia em uma caixa de adornos cerimoniais, que continha todos os ornamentos e enfeites de danças. Para entregá-la a Doetiro, Yupuri e Yepasuria (ou Namisuria) o Dono da Noite preparou uma cerimônia. Ao entregá-la explicou a eles cada objeto que continha a caixa 
e como eles deveriam ser utilizados posteriormente. Disse ainda que nos quatro pontos cardeais existiam ganchos que pendiam a noite. Depois da meia noite ensinou a desmanchar a amarração dos ganchos que seguravam a caixa, e como eles deveriam guardar os instrumentos e ornamentos, após um movimento de dança. Isso foi feito até o amanhecer e é por isso que os baya (mestres de dança) dançam até hoje durante toda a noite. Os irmãos abriram a caixa antes do combinado e deixaram sair uma nuvem escura, chuvisco e temporal. $\mathrm{O}$ único que conseguiu seguir as recomendações do Dono da Noite foi Yepasuria, que se ornamentou, pronunciando o nome de cada enfeite e juntando-os. A meia noite começou a reza desmanchando os ganchos presos nas quatro direções. Começou a tirar e guardar os ornamentos, assim o dia começou a chegar. Assim que começou o dia e a noite.

Através da leitura articulada destas narrativas é possível afirmar que os Tukano correlacionam as constelações, os ornamentos cerimoniais e as estrelas siõkhã, delineando assim um significado profundo para as constelações na cosmologia Tukano.

\section{Notas}

1 Este artigo consiste em uma versão ampliada dos argumentos apresentados em Oliveira (2010) e Epps \& Oliveira (2013), e de diálogos realizados com interlocutores Tukano, moradores do médio e alto Tiquié, TI Alto Rio Negro, durante minha participação como antropóloga do Programa Rio Negro do Instituto Socioambiental, em uma pesquisa colaborativa sobre ciclos e calendários Tukano entre os anos de 2005 e 2010, especialmente na investigação sobre astronomia Tukano realizada pelos Tukano e Desana da Associação da Escola Indígena Tukano Yupuri e Associação das Comunidades Indígenas do médio Tiquié, que teve a consultoria do físico Walmir Thomazzi Cardoso, da Pontifícia Universidade Católica de São Paulo e da Sociedade Brasileira para o Ensino da Astronomia. Ver Cardoso (2007), Aeity \& Acimet (2008) e Azevedo, Oliveira et all (2010).

2 Neste artigo grafarei Tukano em referência aos grupos que compõem a família linguística Tukano Oriental: Tukano, Tuyuka, Kubeo, Desana, Uanana, Pira-Tapuya, Bará, Barasana, Makuna, Tatuyo, Taiwano, Karapanã, Siriano, Yuruti, Miriti-Tapuya, Arapaso, Letuama, Pisá-mira, Tanimuka e Tukano; para este último propriamente dito verver Cabalzar 2008; Oliveira 2010; Azevedo et al 2010). 
Ver Koch-Grünberg (2009 [1905], 2005[1909]) para os Mirití Tapúya e Kubeua; Silva (1962) para os Pira Tapuia e Tukano; Hugh-Jones (1979, 1981) para os Barasana; Correa (1987) para os Cubeo; Gerard-Dolmatoff (1997), Ribeiro \& Kenhíri (1995) e Diakuru \& Kisibi (2006) para os Desana; Aeitt $(2005,2008)$ para os Tuyuka; Aeity \& Acimet (2008), Cardoso (2007), Azevedo et al (2010), Oliveira (2010), Cabalzar et al (2010) para os Tuyuka, Tukano e Desana do rio Tiquié, e Hugh-Jones (2015) sobre a origem da noite entre os Tukano.

$4 \quad \mathrm{Na}$ narrativa de Nahuri Miguel Azevedo, Tukano, clã Hausirõ porã (Nahuri \& Kumaro 2003) o Avô do Universo (Umukho Nehktt) criou este mundo e através do sopro do cigarro, a primeira humanidade, Gente do Aparecimento: Yepa Oãkhtt, ou Yepa Muhipu (Lua), Dehsubari Oãkht, Warãri Oakht, Yupuri Basebo, Buhtuiari Oãkht (homens) e Amõ ou Yepario, Yupahkó, Yepáñiõ, Pirõ Duhigó (mulheres). Através dos conhecimentos obtidos com o Avô do Universo Yepa Oãkhtt criou a segunda humanidade: Doetiro, Yupuri e Buú (homens) e Yepario, Yupahko, Duhigo (mulheres). No processo de formação da humanidade atual os primeiros humanos se transformaram em pássaros, atravessaram o céu pela Via Láctea, adentraram no Lago de Leite, se transformaram em peixe, realizaram uma viagem no ventre de uma Cobra Canoa, a anaconda ancestral, ao longo do Rio de Leite, e finalmente emergiram na terra através do Buraco da Transformação, como, Pamuri mahsã, Gente da Transformação.

5 Termo utilizado localmente pelos indígenas.

6 Dentre as várias espécies de manivas os kumua Tukano consideram algumas 'manivas-chefe', pois são aquelas que surgiram no início do mundo (Ñahuri \& Kumarõ 2003). Cabalzar afirma que "Assim como os homens, organizados em grupos nomeados e hierarquizados, os peixes também estão agrupados, têm seus chefes, bayaroa e kumua..." (2005:76).

7 Trajetória aparente do sol sobre a esfera celeste.

8 Estes 'irmãos chefes' ancestrais dos Tukano também são associados ao planeta Vênus. Na versão do Ñahuri Miguel Azevedo, a aparição matutina de Vênus corresponde a Seribhi, irmão menor, e a aparicão noturna corresponde a Doe, irmão maior, que por não obedecerem aos conselhos de seu pai, Basebo, foram jogados por ele, em direções opostas do mundo, leste e oeste. Ao serem colocados em seus lugares se transformaram em Ñohkoa Mahsã (gente estrela), Seribhi siõkha e Doe siõkha. (Ñhuri \& Kumarõ 2003:97).

9 Desde o início dos anos 2000, os Tukano do rio Tiquié, através de suas associações, em parceria com o ISA, vem desenvolvendo a pesquisa Calendário Anual do rio Tiquié (ver Cabalzar 2010 e 2016), que se insere em um plano mais amplo de manejo ambiental da bacia do rio Tiquié. Desde então têm sido desenvolvidas atividades de pesquisa, monitoramento e registro a partir dde uma perspectiva intercultural, que engloba o acompanhamento e registro de um calendário anual concernente aos saberes cotidianos sobre movimentos das constelações, ciclos de espécies de frutas e animais, seus ambientes, as épocas corretas e técnicas necessárias para realização de atividades econômicas, bem como a realização de atividades rituais. A pesquisa gerou publicações nas línguas indígenas e em português e o site Ciclos anuais dos povos indígenas do Tiquié, que dispõe, na forma de calendários circulares anuais digitais, os resultados da pesquisa por ciclos anuais a partir de 2005, 
a explicação sobre o calendário dos povos indígenas do Tiquié, a descrição de um ciclo anual ideal, a pesquisa colaborativa, e narrativas sobre a noção de manejo do mundo e mudanças climáticas, do ponto de vista dos povos Tukano.

10 Hugh-Jones (1981:235-236) retoma o argumento de Lévi-Strauss no primeiro volume de Mitológicas, de que o barulho está associado a um movimento de disjunção entre terra e sol, ao 'rotten world', expressão usada para conotar fenômenos como a longa noite, inundações catastróficas e eclipses.

11 O que também ocorre em versões Tukano dos mesmos mitos (Ver Ñahuri \& Ktrmaro 2003).

12 Pássaros tesoura, outro tipo de pássaro, andorinhas.

13 Tecido pelas mulheres a partir de folhas de curauá que são secas e desfiadas. Sobre o tecido são formados padrões de desenho e após secar ao sol é tingido com tabatinga amarela. (Aeitu 2005:173).

14 Os colares utilizados pelos dois dançarinos principais em rituais de Kahpiwaia são feitos com quatro dentes de onça. Para fazer cintos tem que arrancar os dentes, furar e enfiar em cordão de curauá. O osso das onças é utilizado para fixar o pente e as penas de garça, e pendurar a corda de pelos de guariba, usados nas costas do dançador. Os pêlos das onças podem ser utilizados para fiar o curauá do qual são feitas estas cordas (Aeitu 2005:170-174).

\section{Referências}

AZEVEDO, V. et al. 2008. Mari Kahtiri Ukuri Turi (Livro dos Tukano sobre nossa Vida neste Mundo). São Paulo: Tipo Gráfico comunicação.

AZEVEDO, V. et al. 2010. "Calendário astronômico do médio rio Tiquié". In CABAlZAR, A. (ed.): Manejo do Mundo. Conhecimentos e práticas dos povos indigenas do rio Negro, noroeste amazônico. São Paulo/ São Gabriel da Cachoeira: ISA-Instituto Sócioambiental/FOIRN-Federação das Organizações Indígenas do Rio Negro.

AZEVEDO, M. et al. 2010. "Manejo ambiental e pesquisa do calendário anual no rio Tiquié". In CABALZAR, A. (ed.): Manejo do Mundo. Conhecimentos e práticas dos povos indígenas do rio Negro, noroeste amazônico, pp. 46-55. São Paulo/ São Gabriel da Cachoeira: ISA-Instituto Sócioambiental/FOIRN-Federação das Organizações Indígenas do Rio Negro.

RIBEIRO, B. G. \& KENHÍRI, T. 1987. "Chuvas e constelações". Ciência Hoje, 6(36):26-35.

AEITU. 2005. Wiseri makañe, Nirõ Makañe. Casa de Transformação - Origem da vida ritual Utapinopona-Tuyuka. São Gabriel da Cachoeira/São Paulo: AEITU/ISA:.

2009. Bureko Watotire. São Paulo/São Gabriel da Cachoeira: Instituto Socioambiental/FOIRN- Federação das Organizações Indígenas do Rio Negro/Associação Escola Indígena Utapinopona Tuyuka. 
AEITY \& ACIMET. 2008. Mari kahtiri pati kahse ukuri turi. São Paulo/São Gabriel da Cachoeira: Instituto Socioambiental/FOIRN/Associação Escola Indígena Tukano Yupuri/Associação das Comunidades Indígenas do Médio Tiquié.

BRUZZI DA SILVA, Alcionilio. 1962. A Civilização Indígena do Uaupés. São Paulo: Linográfica Editora.

CABALZAR, Aloísio (ed.). 2005. Peixe e Gente no Alto Rio Tiquié: conhecimentos tukano e tuyuka, ictiologia, etnologia. São Paulo: Instituto Socioambiental.

CARDOSO, Walmir T. 2007. O Céu dos Tukano na Escola Yupuri. Construindo um calendário dinâmico. Tese de Doutorado. São Paulo: PUC.

COUTO DE MAGALHÃES, J.V. 1955. "Introdução". In RONDON, C. M. (ed.): Indios do Brasil. Norte do Rio Amazonas, p. . Rio de Janeiro: Ministério da Agricultura-Conselho Nacional de Proteção aos Índios.

CORREA, F.R. 1987. “Tiempo y Espacio en la Cosmologia de los Cubeo”. In Etnoastronomias Americanas. Ata do 45 Congresso de Americanistas, pp. 137-168. Bogotá: Universidad Nacional de Colombia,.

EPPS, P. \& OLIVEIRA, M. 2013. "The Serpent, the Pleiades, and the Onelegged Hunter: Astronomical themes in the Upper Rio Negro”. In EPPS, P. \& STENZEL, K. (eds.): Upper Rio Negro: cultural and linguistic interaction in Northwestern Amazonia. Rio de Janeiro: Museu do Índio - FUNAI/Museu Nacional.

FERNANDES, A. C. (DIAKURU) \& FERNANDES, D. M. (KISIBI). 2006. Bueri Kãdiri Marĩriye. Os ensinamentos que não se esquecem. Santo Antônio, Rio Tiquié: UNIRT/FOIRN.

HUGH-JONES, Stephen. 1979. The palm and the Pleiades: initiation and cosmology in northwest Amazonia. London: Cambridge University Press.

. 1982. "The Pleiades and Scorpius in Barasana cosmology." In AVENI, A. \& URTON, G. (eds.): Ethnoastronomy and Archaeoastronomy in the American Tropics, pp. 183-202. New York: ${ }^{*}$ Annals of the New York Academy of Sciences. . 2014. "Caixa de pandora: estilo alto-rio-negrino." R@U - Revista de Antropologia da UFSCar, 6(1):155-173.

2015. "A origem da noite e por que o sol é chamado de folha de caraná". Revista de Sociologia e Antropologia. V.5:03: 659, 697. Dezembro de 2015.

KOCH-GRÜNBERG, Theodor. 2009 [1905]. Começos da Arte na selva. Desenhos manuais de indígenas colecionados por Dr. Theodor Koch-Grünberg em suas viagens pelo Brasil. Manaus: Universidade Federal do Amazonas/IGHA.

. Dois anos entre os indígenas: viagens ao noroeste do Brasil (1903-1905). Manaus: EDUA e FSDB, 2005 [1909].

NAHURI \& KUMARO. 2003. Dahsea Hausirõ porã ukũshe wiophesase mera bueri turi- Mitologia Sagrada dos Tukano Hausirõ Porá. Unirt/FOIRN: São Gabriel da Cachoeira, Coleção Narradores Indígenas, volume 5.

OLIVEIRA, M. 2016. Sobre casas, pessoas e conhecimentos: uma etnografia entre os Tukano Hausirõ e Nahuri do médio rio Tiquié, Noroeste Amazônico. Tese de Doutorado. Florianópolis: UFSC. 
OliVEIRA, M. 2010. "Astronomia Tukano. Através do universo: as constelações na cosmologia dos grupos Tukano do Tiquié". ISA. Povos Indígenas no Brasil (https://pib.socioambiental.org./pt/c/no-brasil-atual/modos-de-vida/ astronomia-tukano; acesso em 10/05/2017).

RAMIREZ, Henri. 1997. A Fala Tukano dos Ye’pâ-Masa. (Gramática, Dicionário e Método de Aprendizagem). Manaus: Inspetoria Salesiana da Amazônia Cedem

REICHEL-DOLMATOFF, Gerardo. 1997. Chamanes de la Selva Pluvial: ensayos sobre los indios Tukano del Noroeste Amazónico. Devon: Themis Books.

\begin{abstract}
This article aims to present some anthropological notes on the astronomical conceptions of the Tukano, demonstrating their articulation with notions related to social organization and cosmology. More specifically, it will deal with the Tukano classification of the constellations and their categorization as Star People (Nohkoa Mahsã), the registration of names and lists of Tukano constellations in the anthropological literature, the relations established by the Tukano between the cycle of constellations and other annual cycles and about the image of the constellations in Tukano mythology highlighting its deep ritual significance.
\end{abstract}

Keywords: Astronomy; Cosmology; Tukanoan; Northwest Amazon.

Recebido em fevereiro de 2017.

Aprovado em junho de 2017. 